\title{
Avian influenza: Myth or mass murder?
}

\author{
Carol Louie
}

The present review article was developed by a grade 12 student for
an international baccalaureate credit in biology at the high school level

C Louie. Avian influenza: Myth or mass murder? Can J Infect Dis Med Microbiol 2005;16(3):197-201.

The purpose of the present article was to determine whether avian influenza (AI) is capable of causing a pandemic. Using research from a variety of medical journals, books and texts, the present paper evaluates the probability of the AI virus becoming sufficiently virulent to pose a global threat.

Previous influenza A pandemics from the past century are reviewed, focusing on the mortality rate and the qualities of the virus that distinguish it from other viruses. Each of the influenza A viruses reviewed were classified as pandemic because they met three key criteria: first, the viruses were highly pathogenic within the human population; second, the viruses were easily transmissible from person to person; and finally, the viruses were novel, such that a large proportion of the population was susceptible to infection.

Information about the H5N1 subtype of AI has also been critically assessed. Evidence suggests that this AI subtype is both novel and highly pathogenic. The mortality rate from epidemics in Thailand in 2004 was as high as $66 \%$. Clearly, this virus is aggressive. It causes a high death rate, proving that humans have a low immunity to the disease.

To date, there has been little evidence to suggest that AI can spread among humans. There have been cases where the virus has transferred from birds to humans, in settings such as farms or open markets with live animal vending. If AI were to undergo a genetic reassortment that allowed itself to transmit easily from person to person, then a serious pandemic could ensue, resulting in high morbidity and mortality. Experts at the World Health Organization and the United States Centers for Disease Control and Prevention agree that AI has the potential to undergo an antigenic shift, thus triggering the next pandemic.

Key Words: Avian influenza; Human transmission; Pandemic; Pathogenicity

vian influenza (AI) has been the focus of newspaper A headlines since the spring of 2004. Experts believe that AI has potential to trigger a pandemic in the human population. Influenza $\mathrm{A}$ is a highly contagious viral illness that can spread by inhalation or direct contact. The influenza A virus has two surface antigens - hemagglutinin and neuraminidase (1). If an antigenic shift or significant alteration occurs to one of these two key antigens, the creation of a new and virulent pathogen could result, one to which most of the population would be susceptible.

Despite recent media attention, $\mathrm{AI}$ is not a new virus; in fact, wild waterfowl are a reservoir for many AI viruses. The comingling of humans with domestic poultry infected with AI

\section{La grippe aviaire : Mythe ou hécatombe?}

Le présent article a pour but de déterminer si la grippe aviaire est capable de causer une pandémie. À partir des recherches publiées dans revues médicales et d'autres types d'ouvrages, l'auteur se propose d'évaluer la probabilité que le virus de la grippe aviaire devienne suffisamment virulent pour représenter une menace d'envergure plus globale.

L'article passe en revue les pandémies d'infections causées par le virus de la grippe A, en mettant l'accent sur le taux de mortalité et les propriétés distinctives de ce virus. Chacun des sous-types du virus de la grippe A a été classifié comme pandémique parce qu'il répond à trois critères clés, c'est-à-dire pathogénicité et contagiosité importantes chez l'être l'humain et forte sensibilité d'une proportion appréciable de la population à son endroit à cause de son arrivée relativement récente.

Les données recueillies sur le sous-type H5N1 du virus de la grippe A ont aussi été évaluées de manière critique. Ainsi, selon les preuves disponibles, ce sous-type est récent et très pathogène. Le taux de mortalité associé aux épidémies qui se sont déclarées en Thaïlande en 2004 a atteint les 66 \%. De toute évidence, ce virus est très infectieux. Il entraîne un fort taux de mortalité, ce qui prouve que l'être humain est peu immunisé contre lui.

À ce jour, peu de preuves indiquent que le virus de la grippe aviaire propage d'une personne à l'autre. Dans certains cas, le virus a été transmis aux humains par des oiseaux dans des environnements précis, comme des fermes ou des marchés où se fait le commerce d'animaux vivants. Par contre, si l'infection aviaire subissait une recombinaison phénotypique qui lui permettait de se propager facilement d'une personne à l'autre, il pourrait en découler une grave pandémie, associée à une morbidité et à une mortalité substantielles. Les experts de l'Organisation mondiale de la santé et des Centers for Disease Control and Prevention des États-Unis s'entendent pour dire que la grippe aviaire a le potentiel de subir des mutations antigéniques, ce qui déclenchera la prochaine pandémie.

Sir Winston Churchill Secondary School, Vancouver, British Columbia

Correspondence: Carol Louie, Sir Winston Churchill Secondary School, 7055 Heather Street, Vancouver, British Columbia V6P 3 P7.

Telephone 604-273-8360, fax 604-270-0462, e-mail carol.louie@shaw.ca

Received for publication January 10, 2005. Accepted April 4, 2005 
TABLE 1

Summary of the three pandemics of the 20th century

\begin{tabular}{lcccc}
\hline Name of influenza & Subtype & Year & Origin of genes & $\begin{array}{c}\text { Deaths } \\
\text { worldwide }\end{array}$ \\
\hline Spanish influenza & H1N1 & $1918 / 1919$ & $\begin{array}{c}\text { Had mammalian } \\
\text { and avian genes }\end{array}$ & $25-50$ million \\
Asian influenza & H2N2 & 1957 & $\begin{array}{c}\text { Avian virus } \\
\text { reassortment }\end{array}$ & 1 million \\
Hong Kong influenza & H3N2 & 1968 & $\begin{array}{c}\text { Avian virus } \\
\text { reassortment }\end{array}$ & 1 million \\
\hline
\end{tabular}

H Hemagglutinin; N Neuraminidase

\section{RESEARCH QUESTION}

\section{Could AI cause a major pandemic?}

Scientists predict that humans are due for a major influenza pandemic. Since the 1600s, pandemics have occurred every 10 to 40 years. The last outbreak emerged in 1968; thus, experts anticipate a pandemic within the next five years. Whether AI will be the cause of the next outbreak is a subject of much concern.

By reviewing previous pandemics, current knowledge and the opinions of a variety of experts, the present paper will discuss the probability of AI causing the next worldwide pandemic.

\section{METHODS}

Current medical literature on the influenza A virus was reviewed, with a focus on articles about AI. This review was followed by discussions with local experts; specifically, with influenza communicable disease epidemiologists. Finally, all of the information was synthesized to assess the probability of AI initiating a pandemic.

\section{INFLUENZA A}

There are three types of influenza - A, B and C. Influenza viruses are members of a family of viruses called Orthomyxoviridae. Influenza $\mathrm{A}$ is the only one of the three influenza viruses that can cause a pandemic because it has the potential to infect both humans and animals. All human influenza A viruses have a distant origin in fowl.

The viral structure of influenza A consists of a protein coat surrounding a segmented RNA genome (4). The segmented genome facilitates a unique feature of genetic mixing called reassortment. The virus is divided into subtypes based on hemagglutinin and neuraminidase proteins located on the surface of the virus (1). The hemagglutinin antigen enables the virus to adhere to host cells (5). Neuraminidase, a glycoprotein, is vital for the process of replication (5). Researchers identify influenza strains by these two surface antigens; for example, the AI present in Asia in 2003 was identified as the $\mathrm{H} 5 \mathrm{~N} 1$ strain.

The disease causes symptoms such as fever, chills, headache and nonproductive cough. Sore throat, nasal congestion, vomiting and conjunctivitis can also occur. The standard duration of sickness is seven to 10 days. Influenza has an incubation period of one to three days and an infectious peak within the first $24 \mathrm{~h}$ after showing symptoms. Those who are over the age of 65 or under five years of age are at the highest risk of dying. Three major pandemics occurred during the 20th century due to different strains of influenza A (Table 1) (1).

\section{PAST PANDEMICS}

The first pandemic of the 1900s was caused by Spanish influenza, which circulated worldwide between 1918 and 1919. Over

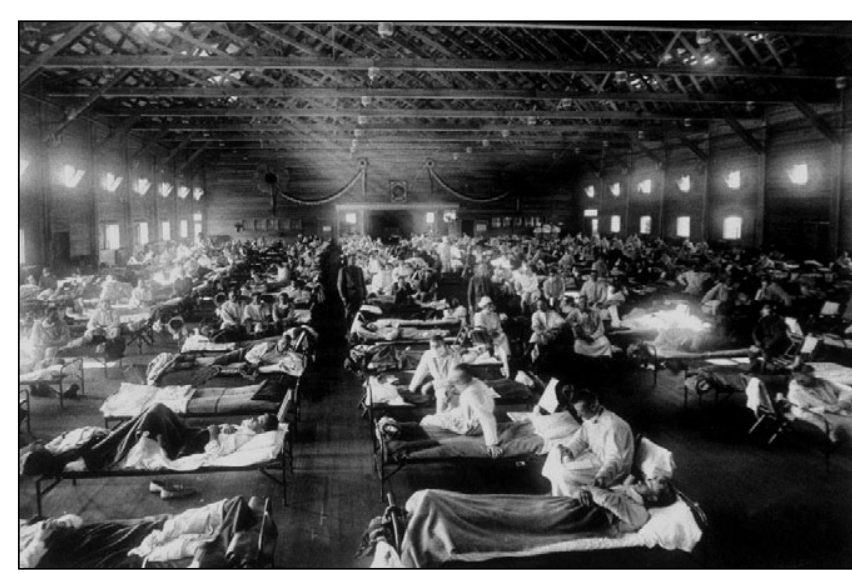

Figure 1) The influenza pandemic of 1918. Reproduced/adapted with permission from reference 20

20 million humans are believed to have died (2). This disease was devastating because of how contagious and lethal it was. Cramped living conditions and close contact during World War One were key factors in the spread of this influenza strain (Figure 1) (6). During the war, approximately 50,000 soldiers died in battle, and influenza killed another 44,000 young men (6). Soldiers carried the virus as they returned home from battle, causing it to spread profusely. In the US alone, 675,000 people died from this influenza strain. The lethality of Spanish influenza separates it from other strains of influenza A. The majority of deaths from most strains of influenza occur in individuals over 65 years of age. However, Spanish influenza also infected "robust, young men...the number of these well developed, well nourished bodies at necropsy made a sad spectacle beyond description", observed a navy officer (6). The virus was so severe that laws were enacted in some cities, enforcing the use of gauze masks at all times and/or forbidding public gatherings (2). If the laws were broken, then individuals were fined or imprisoned (2). Some have hypothesized that the illness spread to Europe, Africa and Asia through seaports in France, Sierra Leone (Africa) and Boston (US) (2). Spanish influenza did not originate from Spain; the reason the illness acquired its name is because of the severity of the epidemic in Spain. Each year, new strains of influenza infect the human race, yet none have been more lethal than the 1918/1919 pandemic. New strains usually represent minor surface protein changes, whereas pandemics are the result of new subtypes caused by a major change in the surface protein of the influenza virus. As a result of this major change, the virus becomes novel to humans.

Another significant pandemic, Asian influenza, occurred in February 1957 (Table 1). It began in China but quickly spread to the US (7). A few outbreaks occurred in the US during the summer of 1957, and in the fall, the H2N2 virus peaked (8). Schools were most affected because of the crowded conditions, allowing the disease to spread easily. Children then infected their families. A vaccine, which was being formulated in May, came into limited supply in August (8). By December 1957, it looked as though the pandemic was under control, but in January and February of 1958, another cluster of cases arose (8). Some believe that the Asian influenza may have infected more people than the Spanish influenza, but due to the rapid identification of the pandemic and use of vaccines, the Asian influenza was not as destructive (8). Overall, approximately 70,000 Americans died due to this outbreak (9). 
Hong Kong influenza, first identified in the early months of 1968, moved into North America in September (Table 1) (8). It became widespread by December, with a total death count of 33,800, making Hong Kong influenza the least destructive pandemic of the 20th century (7). It is hypothesized that this pandemic was milder because it was similar to Asian influenza, in that the neuraminidase surface antigen did not mutate, and therefore the human race had some resistance which reduced the severity of the illness (8). In addition, because the disease peaked in December, schools were out for the holidays, thus causing less human spread (8). Finally, medical treatment of the influenza virus had improved since the last pandemic, and more effective drugs were available (8).

\section{AI}

AI poses a threat to humans because it can be transmitted from birds to humans. Like other strains of influenza, AI can be spread through inhalation. The most common way of catching this malady is through direct contact with infected poultry (8). Also, contamination can occur by means of infected equipment or inhalation of feces that have dried and become airborne (10).

Until this past year, AI had remained relatively mild in humans. It produces symptoms similar to other strains of influenza A. Still, this virus continues to be a threat because humans lack resistance. AI H5N1 was first recorded in humans during 1997 in Hong Kong. While the H5N1 subtype of AI only infected 18 people in Hong Kong, 33\% of those contaminated died $(11,12)$. After six deaths, health officials recommended the slaughter of 1.4 million chickens to prevent the spread of AI $(11,12)$. Despite this attempt to end the risk of disease to Hong Kong residents, two more citizens were diagnosed in the spring of 1997, although both survived $(11,12)$.

In 2003, the H7N7 subtype of AI was found in the Netherlands. This subtype caused 89 cases, but only one death; nevertheless, 30 million chickens were culled (13). The symptoms of this subtype - sore throat, cough, fever and lymphopenia - were not dissimilar to those of common influenza. Some cases also showed signs of conjunctivitis (14). The majority of people infected worked directly with and around contagious chickens. This suggested that the virus remains nontransmissible from human to human.

Between 2003 and 2004, AI subtype H5N1 rapidly spread through birds in many parts of Asia. The countries most affected were Vietnam, which reported 12 deaths out of 22 human cases (15), and Thailand, which reported eight deaths out of 12 cases (66\% mortality rate) later in the same year (7). Although there continues to be little obvious person-to-person transfer of the disease, the concern is that this transfer ability could be acquired through mutation or genetic mixing.

In 2004, H7N3 - the highly pathogenic strain for birds appeared in the Fraser Valley region of British Columbia (16). The virus became rapidly virulent. On February 6, 2004, farmers reported that more chickens were dying than normal, at a rate of approximately eight to 16 deaths per day. Between February 17 and 19, the mortality jumped to 2000 chickens in two days (16). The Canadian Food Inspection Agency (Ottawa) called for the slaughter of infected and healthy flocks. Although only 1.3 million chickens were infected, 19 million chickens were culled. While the disease appeared to be considerable within the poultry population, there were only two confirmed cases of AI in humans (16). Both cases had come in direct contact with sick birds, and neither had been wearing proper eye protection (16).
Furthermore, both cases developed and recovered from conjunctivitis (16). However, this instance was not the first time that the H7 subtype had presented itself; in 2003, the Netherlands was subjected to the H7N7 virus (16). Despite this second appearance in British Columbia, it seems that the H7 subtype of AI does not have the same severity as the H5N1 subtype, which is currently active in Asia. However, this does not diminish the ultimate pandemic potential of $\mathrm{H} 7$ subtypes.

\section{SPREAD/VARIABLES}

The avian virus resides in the intestines of poultry, where it multiplies in number (15). Birds, notably wild waterfowl, have the potential to bear the AI virus without being ill. Influenza has been so long established in wild waterfowl that it now coexists with these birds without causing illness or harm.

When birds defecate, the virus is present in their feces. There are a variety of ways to acquire the virus from the feces, and the virus is able to remain infectious within stool for several months (4).

The most likely way for the virus to infect humans is through direct airway contamination. When dry, the powdered, virusladen feces can travel through the air via wind or other means. In this setting, humans are at risk of inhaling the virus (1). Although this form of transmission does not seem to be a problem in North America, other parts of the world, such as Asia, are faced with this issue due to the prevalence of 'wet markets', which are open markets with live animal vending (4). Since 1970, the conditions within these markets have been conducive to influenza transmission because of the close human and animal contact. Also, the wet markets are an ideal environment for zoonotic transfer, where the virus can mutate in other animals (4).

The virus is also commonly spread when infected migrating birds excrete into water that is used by domestic birds, such as chickens (4). The farmed chickens ingest the diseased excretions and become infected. The virus survives from four to 30 days in water, depending on the temperature; when frozen, it can survive indefinitely (17). The captive, infected chickens can pass the disease onto the farmers, as previously mentioned.

Once domestic birds become infected with AI, there is the possibility of all farms within a given region becoming infected through contaminated farm equipment, such as the trucks used to transport chickens from one farm to another. A truck that has previously carried infected birds may contain infected feces, which in turn may infect healthy chickens at another farm. Feces, and therefore the virus, may be present on truck tires (18).

\section{ANALYSIS OF DISEASE THREAT FROM AI}

$\mathrm{AI}$ is not a major threat to the world - yet. For AI to become a pandemic virus, three major criteria must be met: first, the virus must prove to be highly pathogenic within the human population; second, the virus must become easily transmissible from person to person. For this mutation to ensue, an antigenic shift must take place by mixing the highly pathogenic genes of human influenza with an avian strain (19). Finally, the virus must be novel, so that a large proportion of the population is susceptible. Without available treatment or prevention, the chance of worldwide impact would be high.

Many species of birds are susceptible to AI. Wild waterfowl are a natural reservoir for AI, making it hard to eradicate. Currently, $\mathrm{AI}$ is quite pathogenic within the bird population. Approximately $30 \%$ of poultry in the northern hemisphere are infected by this influenza (4). At any time, mutation or genetic mixing could allow AI viruses to infect humans. 


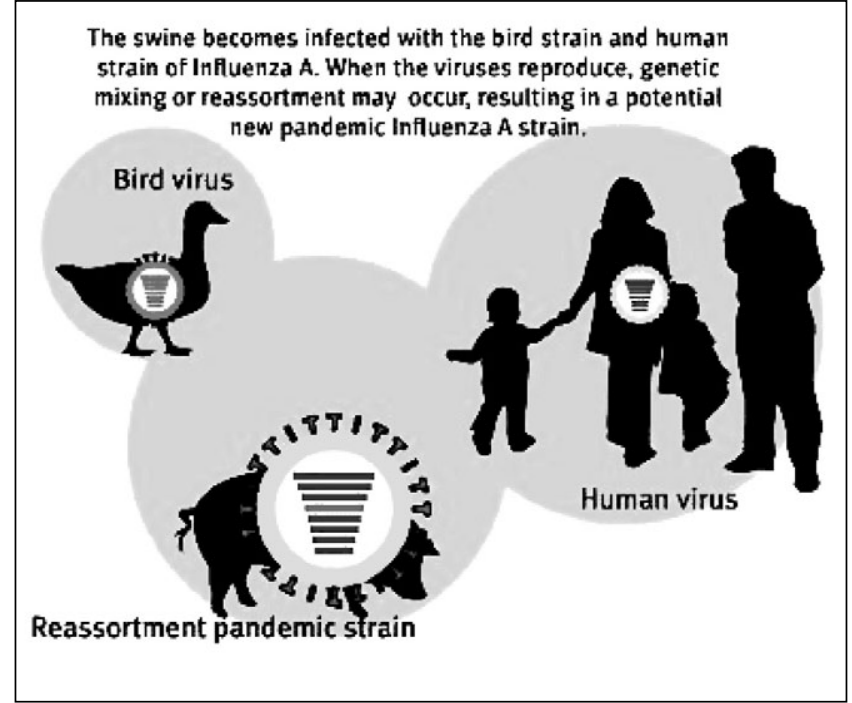

Figure 2) Genetic reassortment between human and nonhuman influenza A viruses. The avian influenza virus mutates by mixing genes from bird and human influenza strains. This mutation may occur in pigs because they can be infected with both viruses without becoming ill; thus, pigs act as a common reservoir. Reproduced/adapted with permission from reference 21

To date, there is little evidence to suggest that AI can be readily transferred from person to person; still, the notion that AI could cause the next pandemic is not irrational. The influenza A virus often undergoes antigenic change. It has a unique ability to combine and trade genetic material with other strains, thus producing a more virulent pathogen (3). This integration of genes is scientifically known as an antigenic shift. The usual host for antigenic shift between these two strains of influenza is pigs because they have the ability to carry both human and avian viruses without becoming ill (Figure 2) (2). The hemagglutinin surface antigen from a human influenza strain could be replaced with the avian equivalent while the virus resides in the pig, thus creating a novel virus (2). This new virus could be highly infectious if it contained genes from regular influenza, which would allow it to transfer throughout the human population, and genes from AI, which would circumvent pre-existing immunity or antibodies. Although the conditions for an antigenic shift seem to be unlikely, experts firmly believe that AI has the potential to undergo this alteration. Peter Cordingley, the regional coordinator for the World Health Organization in Manila, Philippines, has stated that "We don't have any defenses against the disease. If it latches onto a human influenza virus, then it could cause serious international damage" (18).

\section{CONTROL MEASURES}

Strategies have been initiated to prevent the spread of AI, the foremost of which is the massive culling of chickens. Not all poultry that is incinerated and buried is infected with $\mathrm{AI}$; if a chicken is exposed to a diseased chicken at any point, then it is deemed to pose a threat.

The carcasses and all of the supplies that came into contact with the sick chickens are appropriately disposed of. Then, the equipment and facilities that could potentially be contaminated are disinfected. Twenty-one days after sterilization, new birds can be brought to the farms (18). However, even drastic measures such as the slaughter of millions of chickens cannot prevent the return of AI; at any point in time, a wild fowl can fly in and contaminate an entire farm population again (4).

Also, in Hong Kong, a new law that mandates the monthly cleaning of markets has been enacted (4). One day each month, everything in the market is washed and scrubbed simultaneously to ensure that the virus is not transferred within the market setting. Although this may help prevent the spread of influenza, it cannot entirely stop transmission because the chickens produce feces every day, which can be a source of the virus through the month between cleaning days. The only way to end the transfer of the virus through wet markets is by halting the markets altogether.

It is understandable that insecurity regarding AI has evolved because birds have the capability of carrying the disease without showing symptoms (3). Despite attempts to manage the virus, current techniques may not be the ultimate solution. One way of controlling AI is to develop an appropriate vaccination for poultry. This is a tricky undertaking; vaccination can also force evolution of the virus toward further mutations. The slaughter of millions of chickens at a time seems wasteful. As well, there is no proof that humans can obtain the virus through eating cooked chickens (4). The virus is killed at $56^{\circ} \mathrm{C}$ for $3 \mathrm{~h}$ or $60^{\circ} \mathrm{C}$ for $30 \mathrm{~min}$; therefore, if poultry is cooked correctly, there is almost no chance of becoming sick with AI by eating chicken (4).

\section{Treatment of influenza $\mathrm{A}$}

\section{RESEARCH}

The medical community has developed a variety of methods to prevent and treat influenza A. The most effective prevention is vaccination, which is prepared annually. Worldwide, centres for disease control monitor which strains of influenza are most frequent and severe. Based on this surveillance, the three most prevalent strains of the past year are determined. Proteins from these viruses are incorporated into the vaccine to stimulate antibodies against the strains in humans (1). So far, there is no vaccine against AI; however, as soon as the virus shows the ability to transmit easily among humans, public health organizations worldwide will go into high alert to produce the required vaccine en masse.

Amantadine can be given to individuals who have been exposed to influenza A to prevent significant illness (1). Amantadine can be prescribed early in a patient's viral illness to reduce the severity and duration of symptoms (1).

To fight influenza $\mathrm{A}$, drugs such as zanamivir and oseltamivir are useful but can only be taken by patients 13 years of age or older (1). These drugs are relatively new and have been formulated to treat those who have already been infected with the virus by lessening or preventing symptoms (1).

Amantadine has proven useless against the H5N1 and, thus, will probably not be used in patients ill with AI. Zanamivir will not be used because it has been recalled due to side effects. Oseltamivir is the most apt drug to use against AI.

\section{CONCLUSIONS}

Medical experts are expecting an influenza pandemic in the near future. Many researchers believe that AI could trigger this devastating global disease. From the present review of the literature and through discussion with medical experts, it is reasonable to conclude that AI could cause a serious pandemic. AI has already met two important criteria: it is novel and pathogenic. For this virus to trigger the next pandemic, AI must also become easily transmissible within the human race. Because mutation rates are random, humans cannot predict if or when 
this change will occur. Yet, from past experience, it is evident that AI has the ability to alter, making this virus a formidable risk worldwide.

ACKNOWLEDGEMENTS: The author would like to acknowledge and thank Dr Danuta Skowonski, Ms Isabell Willard, Dr Gillian Arsenault, Ms Aleina Tweed, Mr Ken Louie and Dr Heather Louie for reviewing and commenting on the manuscript.

SPONSOR: Ms Willard, Sir Winston Churchill Secondary School, Vancouver, British Columbia.

\section{REFERENCES}

1. American Academy of Pediatrics. Red Book: Report of the committee on infectious diseases, 25th edn. Illinois, American Academy of Pediatrics, 2000.

2. Oldstone M. Viruses, Plagues \& History. New York: Oxford University Press, 1998.

3. Avian Influenza, Public Health Agency of Canada. <http://www.phac-aspc.gc.ca/influenza/avian_e.html> (Version current at May 6, 2005).

4. Trampuz A, Prabhu RM, Smith TF, Baddour LM. Avian influenza: A new pandemic threat? Mayo Clin Proc 2004;79:523-30.

5. Conly J, Johnston L. Influenza - Expect the unexpected. Can J Infect Dis 2004;15:13. Also accessible at <http://www.pulsus.com/Infdis/ 15_01/conl_ed.htm $>$ (Version current at May 6, 2005).

6. Grob G. The Deadly Truth: A History of Disease in America. Cambridge: Harvard University Press, 2000.

7. Avian Influenza (Bird Flu): Implications for Human Disease. <www.cidrap.umn.edu/cidrap/content/hot/avianflu/biofacts/ avflu_human.html $>$ (Version current at May 6, 2005).

8. Avian Influenza (Bird Flu) - Centers for Disease Control and Prevention. <www.cdc.gov/flu/avian> (Version current at May 6, 2005).

9. Influenza Resource Centre. <www.geocities.com/echolswt/flu.html> (Version current at May 6, 2005).
10. Key Facts About Avian Influenza (Bird Flu) and Avian Influenza A (H5N1) Virus - Centers for Disease Control and Prevention. $<$ http://www.cdc.gov/flu/avian/gen-info/facts.htm> (Version current at May 6, 2005).

11. Snacken R, Kendal AP, Haaheim LR, Wood JM. The next influenza pandemic: Lessons from Hong Kong, 1997. Emerg Infect Dis 1999;5:195-203.

12. Yuen KY, Chan PK, Peiris M, et al. Clinical features and rapid viral diagnosis of human disease associated with avian influenza A H5N1 virus. Lancet 1998;351:467-71.

13. Koopmans M, Wilbrink B, Conyn M, et al. Transmission of H7N7 avian influenza $\mathrm{A}$ virus to human beings during a large outbreak in commercial poultry farms in the Netherlands. Lancet 2004;363:587-93.

14. Fouchier RA, Schneeberger PM, Rozendaal FW, et al. Avian influenza A virus (H7N7) associated with human conjunctivitis and a fatal case of acute respiratory distress syndrome. Proc Natl Acad Sci USA 2004;101:1356-61.

15. Avian influenza - World Health Organization. $<$ http://www.who.int/csr/disease/avian_influenza/en> (Version current at May 6, 2005).

16. Human illness from avian influenza H7N3, British Columbia. $<$ http://www.cdc.gov/ncidod/EID/vol10no12/04-0961.htm> (Version current at May 6, 2005).

17. Poultry Health Services. Fowl Plague, Avian Influenza - Highly Pathogenic. <http://www.poultry-health.com/fora/fowlplag.htm> (Version current at May 19, 2005).

18. CBC News Online: Avian Flu - The next pandemic? $<$ http://www.cbc.ca/news/background/flu/avianflu.html> (Version current at May 6, 2005).

19. World Health Organization. Avian influenza - fact sheet. $<$ http://www.who.int/csr/don/2004_01_15/en> (Version current at May 19, 2005).

20. Spellen, A. The Influenza Pandemic of 1918. <pd.ilt.columbia.edu/ banneker/fgproj/influ.htm $>$ (Version current at May 10, 2005)

21. Genetic reassortment between human and nonhuman influenza $A$ viruses. <http://www.nfid.org/library/influenza/img/flu.swf> (Version current at May 10, 2005). 


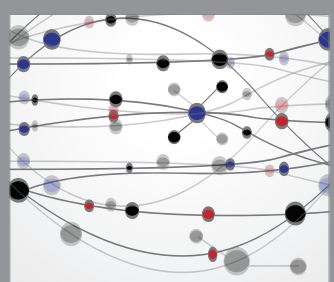

The Scientific World Journal
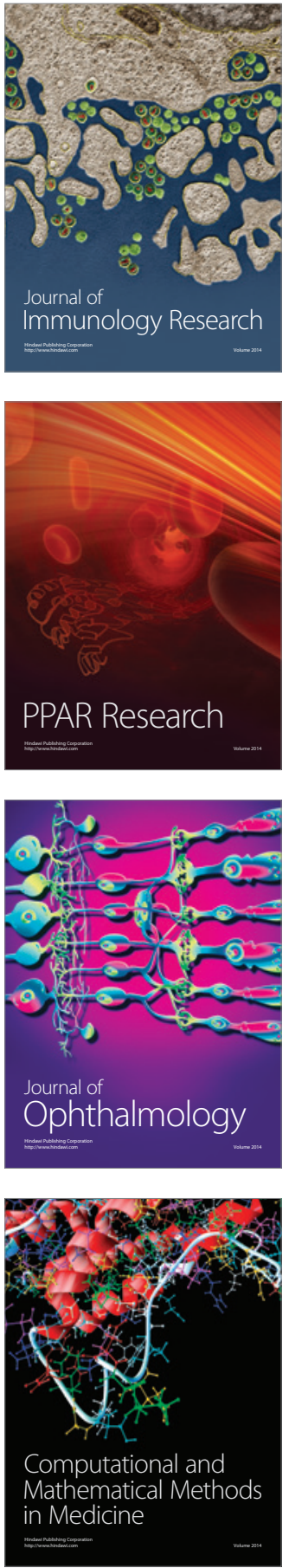

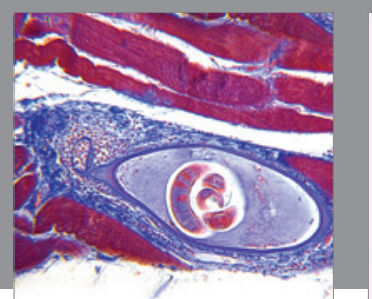

Gastroenterology Research and Practice

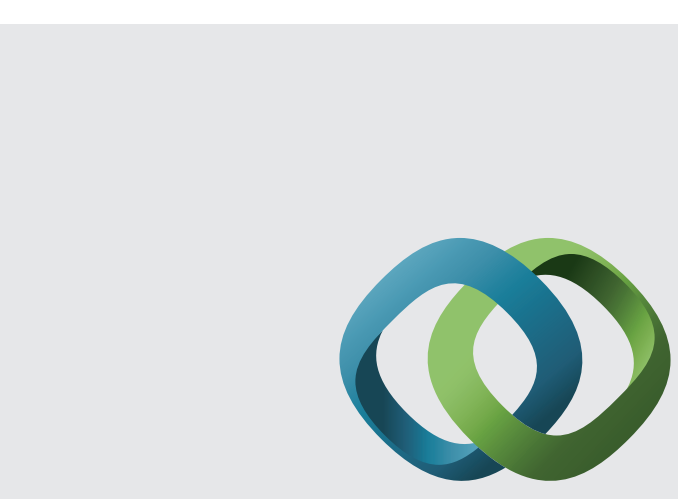

\section{Hindawi}

Submit your manuscripts at

http://www.hindawi.com
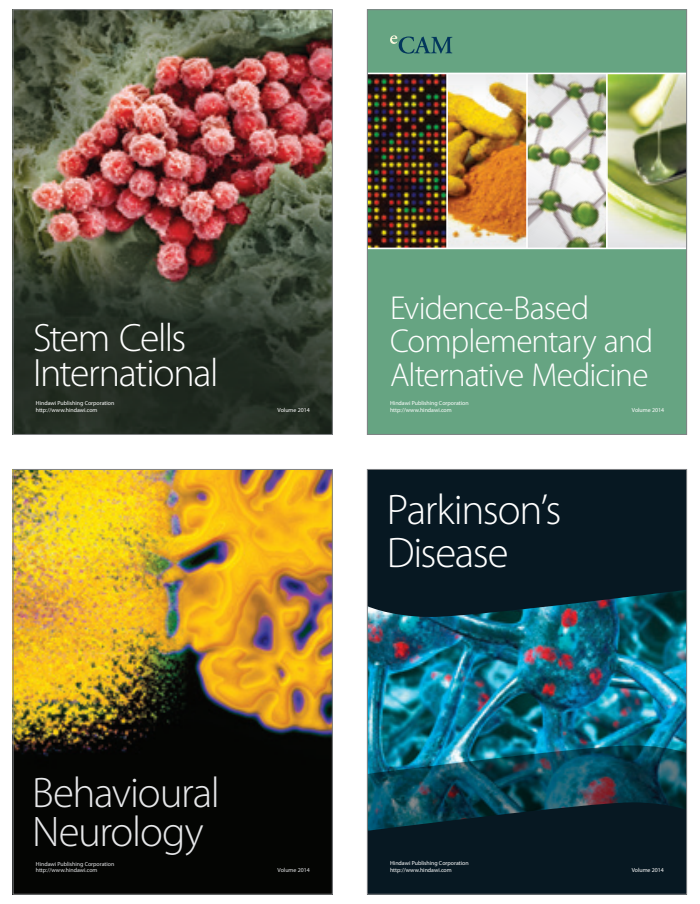
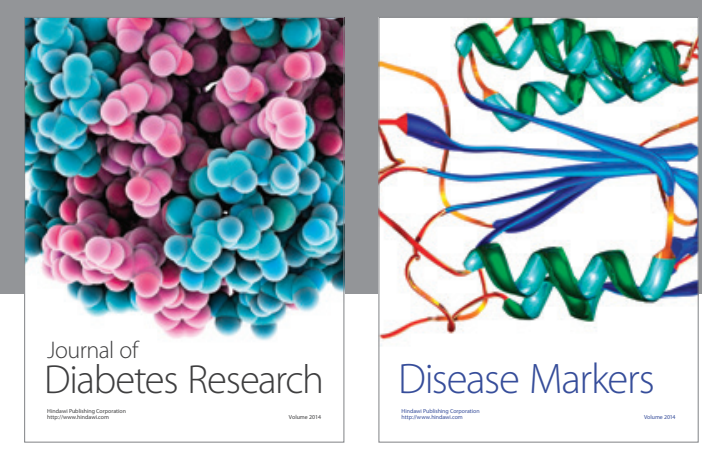

Disease Markers
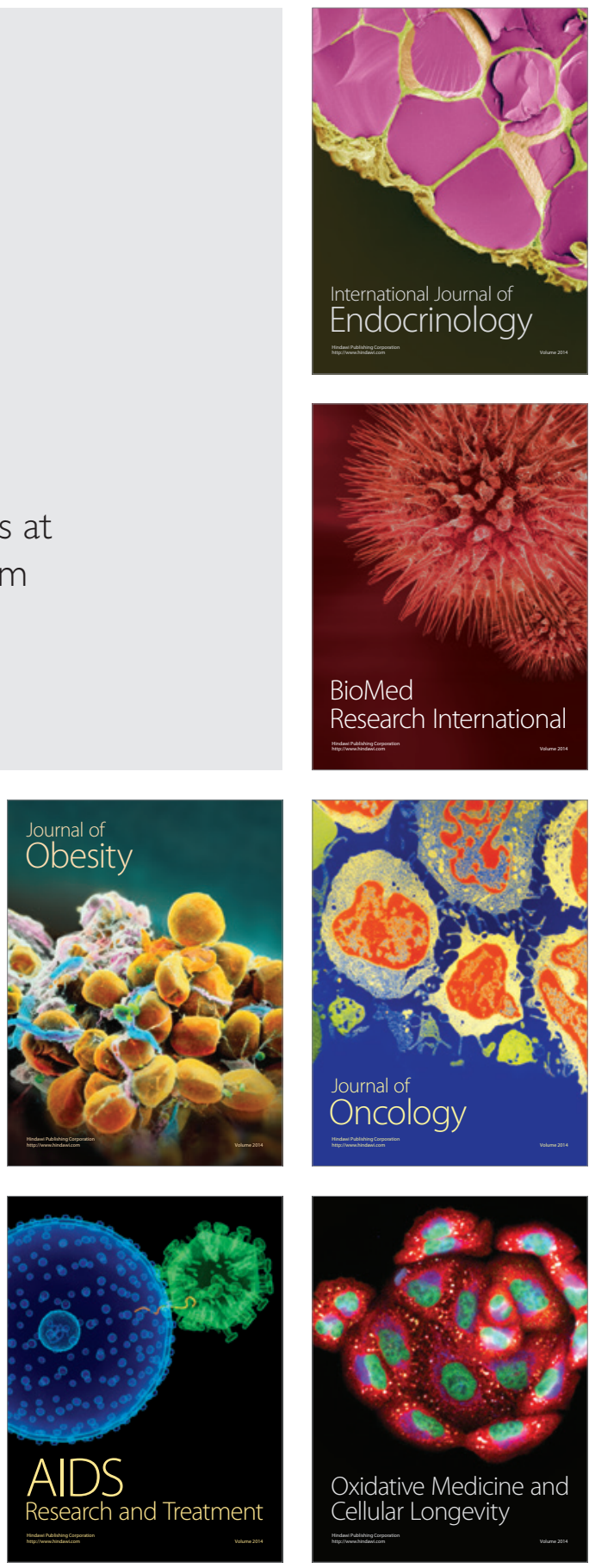